\title{
Contributors
}

\section{Bas Levering}

Associate Professor of Education at the University of Utrecht. His writings have dealt with the foundations of pedagogy as a practical science with a special interest for ordinary language analysis. He edited Theoretische Pedagogiek (Theory of Pedagogy, 1982, with B. Spiecker and A.J. Beekman) and Over het Bijzondere van de Orthopedagogiek (Orthopedagogy as a Special Discipline, 1986, with J.van Weelden).

\section{Siebren Miedema}

Associate Professor, Department of Philosophy and History of Education, Leiden University, the Netherlands. He received his M.A. in education and philosophy from Groningen University and his Ph.D. from Leiden University. His writings have dealt with research methodology, critical pedagogy, philosophy of science, hermeneutical pedagogy, and recently pragmatism. Books include Oriëntatie in de pedagogiek (Orientation in Pedagogy, 1985, with

F. Beugelsdijk); Kennen en handelen. Bijdragen aan het theorie-praktijkdebat in de opvoedingswetenschap (Knowing and Acting. Contributions to the Theory-Practice Debate in Pedagogy, 1986); together with F. Beugelsdijk (Eds.), Pedagogiek in meervoud. Wegen in het denken over opvoeding en onderwijs (Pedagogy in plural. Ways in thinking about pedagogy and education, 1985).

\section{Edmund V. Sullivan}

Dr. Sullivan is joint professor of Applied Psychology and History and Philosophy in Education at the Ontario Institute for Studies in Education, University of Toronto. He has previously taught at Harvard and Simon Fraser Universities. He is the author of numerous books and has contributed many articles to various religious and educational journals. His most recent book is Interpretation of the Personal World: A Critical Psychology, published by Plenum Press, New York.

\section{Renata Tesch}

Director of her own research consulting firm, Qualitative Research Management, she has been interested in the practical and pedagogical aspects of doing research since 1967 when she came to the United States from Germany to earn a degree in Curriculum Research. As one of the cofounders of the Fielding Institute in Santa Barbara, CA, she concentrated on guiding the freedom of creativity and the joy of discovery in research as much as sound knowledge and scholarly standards. Her writings have dealt mostly with methodological issues. Currently her special interests are qualitative analysis and the role the computer can play as the researcher's assistant. 